\title{
Stock Price Reactions to Budget Announcement in Indian Capital Market
}

\author{
Zahid Hassan Kharuri $^{\# 1}$, Dr. T. Manjunatha ${ }^{* 2}$, Dr. V. Rajesh Kumar ${ }^{\# 3}$ \\ ${ }^{\# 1}$ Research Scholar, Visvesvaraya Technological University, Belagavi-590018, Karnataka, India. \\ ${ }^{* 2}$ Professor and Head, Dept. of M B A, Visvesvaraya Technological University B D T College of Engineering, \\ Davangere-577 004, Karnataka, India. \\ ${ }^{\# 3}$ Founder and Managing Partner, Vittam Pravina Gurushala, Bangalore-560011, Karnataka, India.
}

\begin{abstract}
The stock market is an indicator of county's economic strength. The investor will be keen to know the effect of publically available information on the stock prices. The stock prices are quick to respond to announcements of union budgets and external major policy changes for structural reforms. The paper tests the stock prices reactions for union budget announcement by applying event study methodology. The reactions are tested using market model, Abnormal Returns (AR), Average Abnormal Returns (AAR) and Cumulative Average Abnormal Returns (CAAR) for 15 days prior and 15 days after the event date.

Result show that CAARs are significant for most of the days in the event window. The findings of the study support the prediction that budget announcement contains information value and therefore traders can earn abnormal gain on budget announcements in Indian capital market. The future research study could offer scope to conduct similar analysis on other macro-economic events.
\end{abstract}

Keywords: event study, abnormal returns, Average Abnormal Returns, Cumulative Average Abnormal Returns, budget announcement

\section{INTRODUCTION}

The union budget is the most watched event in economic policy making in India. The Government tries to design the union budget in such a way that, it helps the economy to move upwards. The budget expectations tend to affect stock prices due to trading on both prior and after budget. The Indian stock market reacts weak to new information due to lack of transparency of information leading to a less than efficient market. If the market is efficient, then any new information released is immediately reflected in the share price. Event studies, pioneered by Fama et. al. (1969) found that pattern of price adjustment following major events such as mergers, stock splits, changes in firms' dividend policies. Ali and Mustafa (2001) found that change in future prices depends only on arrival of new information that was unpredictable today hence it is based on surprise information. Chhaochharia (2008) analyzed the impact of the information relating to the announcement of stock split and corporate tax reduction on stocks listed on NSE by employing event study. Both the events reflect significantly positive announcement effect. Thereby the study supports the view that Indian stock market is efficient in semi-strong form. Iqbal and Mallikarjunappa (2007; 2008) report that market offers opportunity to earn abnormal returns on cumulative basis after the quarterly earnings announcement and therefore concluded that Indian market is not efficient in the semi-strong form. Cready and Gurun (2010) found that lower earnings results exhibit positive CAAR and move market values higher. Ball and Shivakumar (2008) report that earnings announcements provide a modest but not overwhelming amount of information in relation to the market. Mallikarjunappa \& Manjunatha (2009) found that the results of AARs do not approximate to zero and CAARs show wide fluctuations indicating that abnormal returns can be earned several days after the event day. Hussin et. al. (2010) found that lower earnings lead to negative market reaction. Dutta (2011) examined using t test that the NSE has gradually evolved into a weak form efficient market in 2010-2011. Babu et. al. (2013) analyzed the Union budgets with respect to Indian stock prices and tests the returns from 1991 to 2009. The budget impacted the most extreme effect on stock prices. Datta et. al. (2015) used the paired sample t test and founded that there is a relationship between budget amounts allocated, Nifty, GDP, and market capitalization. The volatility has been observed high during the budget speech time. Singh and Dhamija (2019) found that the economic structure belonging to a country is closely linked with the stock market as found in that nation. Suroto (2020) found that there is a market reaction around events, and the market reacts quickly to absorb information towards a new equilibrium point. Pillai and Pillai (2021) found that the markets were in fact inefficient during the period under study and helps one to understand investor behavior and biases and the different opportunities one could make 
use of, in order to make abnormal profits. Thus it becomes imperative that the fundamentals of a stock market should be an indicator of the budget as presented. The review of the studies shows that there is no clear evidence from the available literature to accept that Indian stock market is efficient in semi-strong form with respect to union budget announcement. Therefore an attempt is made to study the stock price reactions to budget announcement in Indian capital market. The study aims to investigate the stock price reactions to budget announcement and to test the semi strong form of market efficiency in Indian capital market. The results from the study is expected to provide positive vibes to the investors and market to have a predictable impact on stock prices. The stock prices should immediately reflect the budget announcement information and no investors may make abnormal profits. The researcher proposes the need to study the information efficiency in Indian capital market.

The paper is organized in four parts. Part 1 is the introduction; Part 2 presents objectives and methodology; Part 3 presents analysis and results; Part 4 presents the summary and conclusions. References, tables and diagrams are given after Part 4.

\section{Objectives and Methodology}

2.1 We have set following objective:

- To examine the stock price reactions to budget announcement in Indian capital market.

\subsection{Data and Sample:}

This study was based on the 20 sample stocks selected from NIFTY 50 stocks listed on NSE India covering major industries. In this study the following companies have been chosen randomly from NSE NIFTY 50 stocks. Adani Ports and Special Economic Zone Ltd., Asian Paints Ltd., Bajaj Auto Ltd., Britannia Industries Ltd., Divi's Laboratories Ltd., Dr. Reddy's Laboratories Ltd., Eicher Motors Ltd., Hindalco Industries Ltd., Indian Oil Corporation Ltd., ITC Ltd., JSW Steel Ltd., Mahindra and Mahindra Ltd., Maruti Suzuki India Ltd., Oil and Natural Gas Corporation Ltd., Reliance Industries Ltd., Sun Pharmaceutical Industries Ltd., Tata Consumer Products Ltd., Tata Steels Ltd., Titan Company Ltd., and UPL Ltd. For the study we have selected union budget announcement as major economic event in Indian capital market. The data from the year 2001 budget announcement to 2020 were collected for analysis in the study. Data has been collected from NSE website nseindia.com.

\subsection{Methodology:}

Fama et. al. (1969) developed the event study methodology to explore the information content available in corporate announcements. Even today this methodology is widely accepted for extensive use in research. We have used the daily closing prices from NSE Nifty 50 stocks. For the study we have selected 20 stocks data for the period of 20 years. We examine the stock price reactions to the Union Budget announcement by taking the prices before and after the budget announcement. We use a short event window of 31 days to examine how the market reacts. The budget announcement day is taken as the event day.

\section{Statistical Tools}

The secondary data have been analyzed using the following statistical tools:

First, the logarithmic daily returns have been found over the previous day's closing value during the entire 20 year period. Second, the average returns in pre-budget and post-budget period, during the previous 15 and the next 15 days are calculated. We have computed daily stock return, market return, AR, AAR, CAAR for the selected stocks. Further we also computed the t-test using a table value for significance at $5 \%$.

Event Window: $-15 \ldots \ldots . . .0 \ldots . . .15$,

Where 0 is considered as event day, 15 days prior to event day and 15 days after the event day, a total of 31 days surrounding the announcement of Union Budget.

\section{Market Adjusted Model:}

We use market adjusted model to compute the AR and AAR. Under this model, the expected returns are equal across securities. The AR is the difference between security return and market return and this model was given by Cowles (1993) and Latane and Jones (1979). 


$$
\mathrm{AR}_{\mathrm{i}, \mathrm{t}}=\mathrm{R}_{\mathrm{i}, \mathrm{t}}-\mathrm{R}_{\mathrm{m}, \mathrm{t}}
$$

Where $R_{m, t}$ is the return on the Nifty 50 Index.

\section{Average Abnormal Returns (AAR):}

The following model is used to calculate average abnormal return - AARs

$$
A A R_{i t}=\frac{\sum_{i=1}^{N} A R_{i t}}{N} \quad \ldots \ldots \ldots \ldots \ldots \ldots \ldots \text { Eqn. }-2
$$

Where, i represent different securities in the study; $\mathrm{N}=$ total number of securities. $\mathrm{T}=$ the days in the event window.

\section{The Cumulative Average Abnormal Return (CAAR):}

The AAR values are cumulated over 31-day period to find out cumulative average abnormal return (CAARs) and expect that the CAARs should be close to zero. The following formula is used for the CAARs.

$$
C A A R_{t}=\sum_{t=-15}^{K} A A R_{i t}
$$

Where $\mathrm{t}=-15, \ldots \ldots 0, \ldots \ldots+15$

Where, $\mathrm{CAAR}_{\mathrm{t}}$ is the cumulative average abnormal return during the event window period of -15 to +15 days.

\section{Parametric Significance Test}

Parametric $t$ test is used to assess the significance of AARs and CAARs. The 5\% level of significance with appropriate degree of freedom is used. This statistic is given by

$$
\begin{aligned}
& t=\frac{A A R}{\sigma(C A A R)} \\
& t=\frac{C A A R}{\sigma(C A A R)}
\end{aligned}
$$

Where, $\sigma_{(\mathrm{CAAR})}$ is the standard cumulative average abnormal return.

We tested the impact of union budget announcement by using t test and the positive or negative effect of semistrong form of market efficiency analysis for this event study. We test whether the excess returns around the announcement date are different from zero by using the $t$ statistic for the event. $T$ statistics is used to compare the returns of the stocks 15 days prior and 15 days after the event. The 5\% level of significance with appropriate degree of freedom is used for $\mathrm{t}$ test that there are no significant abnormal returns during the event window period of 31 days. We bring out the following analysis to test the objectives.

\section{Results and Analysis}

Table $1 \& 2$ and figure 1 to 20 show the AAR and Table 3 and figure 21 show the values of CAAR values for the sample data of budget announcement for market adjusted model of 2001 to 2020. The significant AARs are observed as positive for market adjusted model for most of the days in the event window. This shows that market is positively responded to the budget announcement. Further the AAR on the event day (0) are positive for 13 years and negative for 7 years. The results of AARs in market adjusted model are positively insignificant for majority of the days in the event window. In particular, on the day of budget announcement (day 0) the AAR is positive and insignificant and on day 1 for the study period. This shows that investors reacted positively on day 1 of the budget announcement news. The results appear to be a small positive trend in event window leading up to positive returns. It shows that budget announcement had a positive impact on the market on the day of budget announcements. The results imply that the investors are able to anticipate the publicly available information and use the same to generate abnormal returns.

To get the robust results, CAAR value was calculated during the event window of 31 days. The CAAR values are found to be positive and significant after the event day for the market model. Further, the CAAR values are 


\section{DOI: $10.51386 / 25815946 /$ ijsms-v4i6p107}

increasing continuously during the window period. This phenomenon indicates that budget announcement yields significant positive abnormal returns when they buy and hold during the budget period. Overall, the $t$ test results indicate that AARs are close to zero and CAARs are not close to zero which generates abnormal return to the investor if they use buy and hold strategy during the budget announcement. This shows that the investors can hold their investment during the budget announcement and generate abnormal profit which is against the theory of EMH. The results prove that budget announcement is a predictable event.

\section{Summary and Conclusion}

The empirical study examines the performance of sample stocks by using market adjusted model. The paper investigated the information content in stock prices on the release of union budget announcement by using event study and cohen et. al. (1983) methodology in this paper. The result of the number of positive and negative AARs and CAARs show that there are more numbers of positive values than negative values during the event window of 31 days. This result shows that market has positively reacted on the release of the union budget announcement information. Therefore, it is concluded that there is a significant difference between the number of positive and negative AAR. The budget announcement information can generate significant abnormal profits to the trades in Indian capital market. These results call for regulatory authorities to make policy changes for the proper dissemination of budget information. This study covered larger sample covering +15 days and -15 days from the event day in Indian capital market. The results obtained from the study can be generalized for investors to be applicable for other economic events such as Goods and Services Tax announcement, monetary policy announcement and other major economic events in the Indian capital market.

\section{References}

[1] Ali, S. S., \& Mustafa, K. (2001). Testing Semi-strong Form Efficiency of Stock Market, The Pakistan Development Review, 40(4), 651-674.

[2] Babu, S.Suresh and Venkateswarlu (2013). Impact of Union Budget on Indian Stock Prices. International Journal of Management Research and Review, 3 (5), 2890-2896.

[3] Ball, R. \& Shivakumar, L. (2008). 'How much new information is there in earnings? Journal of Accounting Research, 46(5), 9751016.

[4] Cohen, K., G. Hawawini, S. Maier, R. Schwartz \& D. Whitcomb (1983). Friction in the trading process and the estimation of systematic risk, Journal of Financial Economics, 264-278.

[5] Cowles, A. (1933). Can stock market forecasters forecast? Econometrica, 1(3), 309-324.

[6] Cready, W.M. \& Gurun, U.G. (2010). 'Aggregate market reaction to earnings announcements', Journal of Accounting Research, $48(2), 289-334$.

[7] Dhar, S. and Chhaochharia, S. (2008), "Market Reactions around Stock Splits and Bonus Issues: Some Indian Evidence", http://ssrn.com/abstract=1087200, http://dx.doi.org/10.2139/ssrn.1087200, 1-24.

[8] Eugune F. Fama, (1969). The Behavior of Stock Market Prices, Journal of Business, 38(1), 34-105.

[9] Gayathri P Pillai and Arjun Pillai (2021). Efficient Market Hypothesis during the Time of COVID. International Journal of Recent Technology and Engineering (IJRTE), 10(1), 21-29.

[10] Hussin, B. M., Ahmed, A.D. \& Ying, T. C. (2010). 'Semi-strong form efficiency: Market reaction to dividend and earnings announcements in Malaysian stock exchange’, IUP Journal of Applied Finance, 16(5), 36-60.

[11] Iqbal and Mallikarjunappa T. (2008). The behaviour of Indian stock prices and returns: Is the stock market efficient? SCOUR Journal of Institute of Productivity and Management, 2(2), 39-46.

[12] Iqbal and Mallikarjunappa, T. (2007). Market reactions to earnings information: an empirical study. AIMS International Journal of Management, May, 1(2), 153-167.

[13] Latane, H., \& C. Jones (1979). Standardized unexpected earrings 1971-1977, Journal of Finance, 34(3), 717-724.

[14] Mallikarjunappa T. and Manjunatha T. (2009). Stock Price Reactions to Dividend Announcements, Journal of Management \& Public Policy, 1(1), 43- 56.

[15] Santanu Dutta (2011) “A Statistical Analysis of Daily Nifty Returns, During 2001-11”, International Journal of Research in Commerce, It \& Management, 1(4), 133-137. 
[16] Singh, K. and Dhamija, A. (2019). Macroeconomic factors as a predictor of stock market: Empirical evidences from India, U.S. and U.K. International Journal of Recent Technology and Engineering, 8(10), 743-751.

[17] Suroto (2020). Market Efficiency Testing Half Strong Form In Indonesia Stock Exchange. SSRG International Journal of Economics and Management Studies, 7(9), 96-101.

[18] Vadali. Sri Ram Datta, Yanamala. Sunil Kumar, Lenina. M, Indukuri Sarika, Allam. Venkata Swamy (2015) “A Study of Budget Impact on Stock Market", Indian Research Journal, 2(1). 1-8.

\section{APPENDIX}

Table 1A Shows Sample Stocks AAR and CAAR from 2001 to 2005

\begin{tabular}{|c|c|c|c|c|c|c|c|c|c|c|}
\hline Period & & & & & & & & 04 & & \\
\hline & AAR & CAAR & AAR & CAAR & AAR & CAAR & AAR & CAAR & AAR & CAAR \\
\hline-15 & -0.001 & -0.001 & -0.013 & -0.013 & -0.002 & -0.002 & -0.002 & -0.002 & 0.006 & 0.006 \\
\hline-14 & 0.003 & 0.001 & 0.014 & 0.000 & 0.002 & 0.000 & -0.003 & -0.005 & 0.012 & 0.018 \\
\hline-13 & 0.010 & 0.011 & 0.001 & 0.002 & -0.003 & -0.003 & 0.000 & -0.005 & -0.005 & 0.013 \\
\hline-12 & 0.006 & 0.017 & 0.022 & 0.024 & 0.001 & -0.002 & -0.005 & -0.009 & 0.005 & 0.019 \\
\hline-11 & 0.000 & 0.017 & 0.004 & 0.028 & 0.001 & -0.001 & -0.004 & -0.013 & -0.001 & 0.018 \\
\hline-10 & -0.002 & 0.015 & -0.013 & 0.015 & 0.003 & 0.002 & 0.016 & 0.002 & -0.009 & 0.009 \\
\hline-9 & -0.002 & 0.013 & -0.010 & 0.005 & 0.000 & 0.002 & 0.004 & 0.007 & 0.002 & 0.011 \\
\hline-8 & -0.008 & 0.004 & -0.010 & -0.006 & 0.005 & 0.007 & -0.003 & 0.004 & -0.004 & 0.007 \\
\hline-7 & -0.004 & 0.001 & 0.025 & 0.020 & -0.007 & 0.001 & 0.003 & 0.007 & -0.005 & 0.002 \\
\hline-6 & 0.016 & 0.016 & 0.002 & 0.021 & 0.000 & 0.000 & -0.005 & 0.003 & 0.004 & 0.006 \\
\hline-5 & -0.002 & 0.014 & -0.005 & 0.016 & 0.004 & 0.004 & 0.006 & 0.008 & 0.002 & 0.008 \\
\hline-4 & -0.005 & 0.010 & -0.007 & 0.009 & -0.001 & 0.003 & 0.000 & 0.008 & 0.001 & 0.008 \\
\hline-3 & 0.003 & 0.012 & 0.003 & 0.012 & 0.002 & 0.004 & 0.004 & 0.012 & -0.003 & 0.006 \\
\hline-2 & 0.007 & 0.020 & -0.019 & -0.007 & 0.001 & 0.006 & 0.005 & 0.016 & -0.004 & 0.002 \\
\hline-1 & -0.023 & -0.003 & 0.000 & -0.008 & 0.004 & 0.010 & 0.001 & 0.017 & -0.004 & -0.002 \\
\hline 0 & 0.010 & 0.007 & -0.004 & -0.011 & 0.007 & 0.017 & -0.005 & 0.013 & 0.002 & 0.000 \\
\hline 1 & 0.005 & 0.012 & 0.012 & 0.001 & -0.001 & 0.015 & -0.002 & 0.011 & -0.003 & -0.003 \\
\hline 2 & -0.006 & 0.006 & -0.015 & -0.015 & -0.007 & 0.008 & -0.004 & 0.006 & -0.003 & -0.006 \\
\hline 3 & 0.000 & 0.006 & -0.010 & -0.024 & 0.001 & 0.009 & -0.008 & -0.001 & 0.003 & -0.003 \\
\hline 4 & -0.020 & -0.013 & -0.022 & -0.047 & 0.000 & 0.009 & 0.007 & 0.005 & 0.002 & -0.001 \\
\hline 5 & 0.001 & -0.012 & 0.013 & -0.033 & 0.000 & 0.010 & -0.001 & 0.005 & -0.002 & -0.003 \\
\hline 6 & -0.005 & -0.017 & 0.001 & -0.033 & -0.002 & 0.008 & 0.001 & 0.006 & -0.007 & -0.009 \\
\hline 7 & 0.007 & -0.010 & -0.005 & -0.038 & 0.002 & 0.010 & -0.002 & 0.004 & 0.003 & -0.006 \\
\hline 8 & -0.028 & -0.039 & -0.003 & -0.040 & -0.002 & 0.009 & -0.006 & -0.003 & 0.001 & -0.005 \\
\hline 9 & -0.007 & -0.046 & 0.000 & -0.040 & 0.000 & 0.009 & -0.005 & -0.008 & -0.003 & -0.008 \\
\hline 10 & 0.020 & -0.026 & 0.000 & -0.040 & -0.002 & 0.007 & 0.000 & -0.008 & -0.001 & -0.008 \\
\hline 11 & 0.007 & -0.019 & -0.001 & -0.041 & -0.007 & 0.000 & 0.006 & -0.002 & -0.001 & -0.009 \\
\hline 12 & 0.006 & -0.012 & -0.002 & -0.043 & -0.013 & -0.013 & 0.002 & 0.000 & -0.010 & -0.019 \\
\hline 13 & 0.007 & -0.005 & -0.005 & -0.048 & 0.007 & -0.006 & -0.007 & -0.007 & -0.011 & -0.030 \\
\hline 14 & -0.009 & -0.014 & 0.013 & -0.036 & 0.004 & -0.003 & -0.001 & -0.007 & -0.007 & -0.037 \\
\hline 15 & 0.009 & -0.005 & 0.005 & -0.030 & 0.005 & 0.003 & 0.000 & -0.007 & -0.006 & -0.042 \\
\hline
\end{tabular}

Source: AAR \& CAAR's are computed by the researchers using equation 1, 2 and 3 for the years.

Note 1: First row of the Table 1A respresents the study period splited into 5years 
Note 2: First column indicates the event window period -15 to +15 days which is explained under the heading methodology

Note 3: Second row and subsequent rows of the table represents the AAR and CAAR computed values explained under the heading equation $2 \& 3$ respectively.

Note 4: The source and notes hold good for the Table 1B, 1C and 1D also.

Table 1B Shows Sample Stocks AAR and CAAR from 2001 to 2005

\begin{tabular}{|c|c|c|c|c|c|c|c|c|c|c|}
\hline \multirow[t]{2}{*}{ Period } & \multicolumn{2}{|c|}{2006} & \multicolumn{2}{|c|}{2007} & \multicolumn{2}{|c|}{2008} & \multicolumn{2}{|c|}{2009} & \multicolumn{2}{|c|}{2010} \\
\hline & AAR & CAAR & AAR & CAAR & AAR & CAAR & AAR & CAAR & AAR & CAAR \\
\hline-15 & 0.002 & 0.002 & 0.005 & 0.005 & -0.003 & -0.003 & 0.008 & 0.008 & 0.003 & 0.003 \\
\hline-14 & -0.010 & -0.007 & -0.002 & 0.003 & -0.020 & -0.023 & -0.002 & 0.006 & 0.016 & 0.019 \\
\hline-13 & 0.007 & 0.000 & -0.009 & -0.006 & -0.009 & -0.031 & -0.004 & 0.002 & -0.001 & 0.019 \\
\hline-12 & -0.001 & -0.001 & -0.032 & -0.037 & 0.020 & -0.012 & -0.009 & -0.007 & 0.014 & 0.033 \\
\hline-11 & -0.004 & -0.004 & -0.006 & -0.043 & 0.013 & 0.001 & -0.001 & -0.008 & 0.005 & 0.038 \\
\hline-10 & 0.003 & -0.001 & 0.010 & -0.033 & 0.011 & 0.012 & -0.005 & -0.013 & 0.015 & 0.053 \\
\hline-9 & 0.003 & 0.002 & 0.023 & -0.009 & 0.005 & 0.017 & 0.005 & -0.008 & 0.011 & 0.065 \\
\hline-8 & -0.019 & -0.017 & 0.006 & -0.004 & 0.000 & 0.017 & -0.003 & -0.011 & 0.023 & 0.088 \\
\hline-7 & 0.003 & -0.014 & -0.005 & -0.009 & -0.002 & 0.015 & -0.005 & -0.016 & 0.015 & 0.103 \\
\hline-6 & 0.008 & -0.007 & 0.004 & -0.005 & 0.005 & 0.020 & 0.009 & -0.007 & 0.018 & 0.120 \\
\hline-5 & 0.000 & -0.007 & -0.009 & -0.014 & -0.007 & 0.013 & -0.001 & -0.008 & 0.014 & 0.135 \\
\hline-4 & 0.000 & -0.006 & -0.020 & -0.034 & 0.002 & 0.015 & 0.003 & -0.004 & 0.009 & 0.144 \\
\hline-3 & -0.006 & -0.012 & 0.009 & -0.026 & -0.001 & 0.014 & 0.006 & 0.001 & 0.010 & 0.154 \\
\hline-2 & 0.010 & -0.002 & -0.010 & -0.036 & 0.015 & 0.029 & -0.002 & -0.001 & 0.010 & 0.164 \\
\hline-1 & -0.004 & -0.006 & -0.025 & -0.060 & 0.011 & 0.041 & -0.002 & -0.003 & 0.008 & 0.172 \\
\hline 0 & 0.008 & 0.002 & 0.009 & -0.051 & 0.011 & 0.052 & 0.020 & 0.017 & 0.015 & 0.187 \\
\hline 1 & 0.005 & 0.007 & -0.007 & -0.058 & 0.008 & 0.060 & 0.012 & 0.029 & 0.015 & 0.202 \\
\hline 2 & -0.003 & 0.004 & -0.039 & -0.098 & -0.002 & 0.057 & -0.004 & 0.025 & 0.007 & 0.209 \\
\hline 3 & 0.020 & 0.024 & 0.004 & -0.094 & -0.003 & 0.054 & -0.010 & 0.014 & 0.006 & 0.215 \\
\hline 4 & -0.010 & 0.014 & -0.003 & -0.097 & -0.002 & 0.052 & -0.008 & 0.007 & 0.005 & 0.220 \\
\hline 5 & -0.030 & -0.016 & 0.030 & -0.067 & -0.001 & 0.052 & -0.003 & 0.004 & 0.009 & 0.229 \\
\hline 6 & 0.003 & -0.013 & -0.003 & -0.070 & -0.015 & 0.037 & 0.003 & 0.007 & 0.009 & 0.237 \\
\hline 7 & 0.007 & -0.005 & 0.011 & -0.059 & 0.005 & 0.042 & -0.002 & 0.004 & 0.004 & 0.241 \\
\hline 8 & -0.002 & -0.008 & 0.020 & -0.038 & -0.021 & 0.021 & 0.015 & 0.019 & 0.018 & 0.259 \\
\hline 9 & -0.005 & -0.012 & -0.022 & -0.060 & -0.008 & 0.013 & 0.001 & 0.020 & 0.008 & 0.268 \\
\hline 10 & 0.001 & -0.012 & 0.013 & -0.047 & -0.008 & 0.005 & -0.007 & 0.013 & 0.011 & 0.279 \\
\hline 11 & 0.001 & -0.011 & -0.010 & -0.056 & -0.006 & -0.001 & 0.003 & 0.016 & 0.008 & 0.287 \\
\hline 12 & 0.007 & -0.004 & 0.012 & -0.045 & -0.012 & -0.013 & 0.014 & 0.030 & 0.004 & 0.291 \\
\hline 13 & -0.002 & -0.005 & 0.007 & -0.037 & -0.003 & -0.016 & 0.014 & 0.044 & 0.008 & 0.299 \\
\hline 14 & -0.001 & -0.006 & 0.013 & -0.025 & 0.009 & -0.007 & 0.004 & 0.049 & 0.014 & 0.313 \\
\hline 15 & -0.002 & -0.008 & 0.019 & -0.006 & 0.003 & -0.004 & 0.008 & 0.056 & 0.013 & 0.326 \\
\hline
\end{tabular}


Table 1C Shows Sample Stocks AAR and CAAR from 2001 to 2005

\begin{tabular}{|c|c|c|c|c|c|c|c|c|c|c|}
\hline \multirow[t]{2}{*}{ Period } & \multicolumn{2}{|c|}{2011} & \multicolumn{2}{|c|}{2012} & \multicolumn{2}{|c|}{2013} & \multicolumn{2}{|c|}{2014} & \multicolumn{2}{|c|}{2015} \\
\hline & AAR & CAAR & AAR & CAAR & AAR & CAAR & AAR & CAAR & AAR & CAAR \\
\hline-15 & -0.012 & -0.012 & -0.103 & -0.103 & 0.003 & 0.003 & -0.011 & -0.011 & 0.003 & 0.003 \\
\hline-14 & 0.000 & -0.013 & 0.094 & -0.009 & 0.022 & 0.024 & 0.005 & -0.006 & 0.003 & 0.005 \\
\hline-13 & -0.004 & -0.017 & 0.033 & 0.024 & 0.024 & 0.049 & 0.001 & -0.004 & 0.002 & 0.007 \\
\hline-12 & -0.003 & -0.020 & -0.024 & 0.000 & 0.019 & 0.067 & 0.006 & 0.002 & 0.006 & 0.013 \\
\hline-11 & 0.005 & -0.015 & 0.025 & 0.025 & 0.023 & 0.091 & -0.005 & -0.003 & -0.001 & 0.012 \\
\hline-10 & -0.003 & -0.018 & 0.016 & 0.040 & 0.011 & 0.102 & 0.001 & -0.002 & 0.006 & 0.017 \\
\hline-9 & -0.010 & -0.028 & -0.046 & -0.006 & 0.017 & 0.119 & 0.009 & 0.007 & 0.009 & 0.026 \\
\hline-8 & -0.004 & -0.032 & -0.030 & -0.036 & 0.033 & 0.152 & 0.008 & 0.016 & 0.006 & 0.032 \\
\hline-7 & 0.000 & -0.032 & 0.007 & -0.030 & 0.017 & 0.170 & 0.001 & 0.016 & 0.002 & 0.034 \\
\hline-6 & -0.003 & -0.035 & 0.110 & 0.081 & 0.013 & 0.183 & 0.000 & 0.016 & -0.002 & 0.033 \\
\hline-5 & 0.001 & -0.034 & 0.031 & 0.112 & 0.016 & 0.199 & -0.001 & 0.015 & -0.009 & 0.023 \\
\hline-4 & 0.007 & -0.027 & 0.076 & 0.188 & 0.012 & 0.211 & -0.009 & 0.006 & -0.004 & 0.019 \\
\hline-3 & -0.013 & -0.039 & 0.048 & 0.236 & -0.001 & 0.210 & 0.001 & 0.006 & -0.003 & 0.017 \\
\hline-2 & -0.003 & -0.043 & -0.049 & 0.187 & 0.031 & 0.241 & 0.003 & 0.009 & 0.004 & 0.021 \\
\hline-1 & 0.016 & -0.027 & -0.022 & 0.165 & 0.010 & 0.250 & 0.002 & 0.011 & -0.005 & 0.015 \\
\hline 0 & 0.008 & -0.018 & -0.025 & 0.140 & 0.025 & 0.275 & 0.004 & 0.014 & -0.006 & 0.009 \\
\hline 1 & -0.001 & -0.019 & 0.025 & 0.165 & 0.017 & 0.292 & 0.002 & 0.017 & -0.006 & 0.003 \\
\hline 2 & -0.007 & -0.026 & 0.081 & 0.246 & 0.026 & 0.318 & -0.001 & 0.016 & -0.005 & -0.002 \\
\hline 3 & 0.008 & -0.018 & -0.091 & 0.155 & 0.018 & 0.337 & -0.002 & 0.013 & 0.003 & 0.001 \\
\hline 4 & -0.004 & -0.022 & 0.049 & 0.204 & 0.021 & 0.358 & 0.000 & 0.013 & 0.001 & 0.002 \\
\hline 5 & 0.000 & -0.022 & -0.060 & 0.143 & 0.025 & 0.383 & -0.011 & 0.002 & 0.000 & 0.002 \\
\hline 6 & 0.001 & -0.021 & 0.063 & 0.207 & 0.020 & 0.403 & -0.001 & 0.001 & -0.005 & -0.003 \\
\hline 7 & 0.006 & -0.014 & -0.030 & 0.176 & 0.020 & 0.422 & -0.003 & -0.003 & 0.004 & 0.001 \\
\hline 8 & -0.001 & -0.015 & 0.005 & 0.181 & 0.014 & 0.436 & 0.001 & -0.001 & -0.005 & -0.004 \\
\hline 9 & -0.008 & -0.023 & 0.129 & 0.310 & 0.018 & 0.454 & -0.003 & -0.004 & -0.010 & -0.014 \\
\hline 10 & 0.008 & -0.015 & 0.035 & 0.346 & 0.027 & 0.481 & 0.001 & -0.003 & 0.012 & -0.002 \\
\hline 11 & -0.003 & -0.019 & 0.051 & 0.396 & 0.016 & 0.498 & -0.001 & -0.004 & -0.001 & -0.003 \\
\hline 12 & -0.005 & -0.024 & -0.006 & 0.390 & 0.008 & 0.506 & 0.006 & 0.003 & 0.004 & 0.001 \\
\hline 13 & 0.006 & -0.017 & -0.064 & 0.327 & 0.011 & 0.517 & 0.007 & 0.010 & -0.009 & -0.008 \\
\hline 14 & 0.006 & -0.011 & 0.019 & 0.345 & 0.016 & 0.533 & -0.004 & 0.006 & 0.006 & -0.003 \\
\hline 15 & -0.002 & -0.013 & 0.000 & 0.346 & 0.008 & 0.541 & 0.000 & 0.005 & 0.000 & -0.002 \\
\hline
\end{tabular}

Table 1D Shows Sample Stocks AAR and CAAR from 2001 to 2005

\begin{tabular}{|c|c|c|c|c|c|c|c|c|c|c|}
\hline Period & \multicolumn{2}{|c|}{2016} & \multicolumn{2}{c|}{2017} & \multicolumn{2}{c|}{2018} & \multicolumn{2}{c|}{2019} & \multicolumn{2}{c|}{2020} \\
\hline & AAR & CAAR & AAR & CAAR & AAR & CAAR & AAR & CAAR & AAR & CAAR \\
\hline-15 & 0.006 & 0.006 & 0.002 & 0.002 & 0.041 & 0.041 & -0.002 & -0.002 & 0.007 & 0.007 \\
\hline-14 & -0.002 & 0.004 & -0.006 & -0.004 & 0.043 & 0.084 & 0.001 & -0.002 & 0.009 & 0.015 \\
\hline-13 & 0.003 & 0.008 & -0.001 & -0.005 & 0.034 & 0.118 & -0.003 & -0.005 & 0.005 & 0.020 \\
\hline-12 & -0.003 & 0.005 & -0.005 & -0.009 & 0.019 & 0.137 & -0.003 & -0.008 & 0.005 & 0.025 \\
\hline
\end{tabular}




\begin{tabular}{|c|c|c|c|c|c|c|c|c|c|c|}
\hline-11 & 0.001 & 0.006 & 0.001 & -0.008 & 0.055 & 0.193 & 0.007 & 0.000 & 0.005 & 0.030 \\
\hline-10 & 0.004 & 0.011 & 0.006 & -0.002 & 0.029 & 0.222 & -0.008 & -0.008 & 0.002 & 0.032 \\
\hline-9 & -0.002 & 0.008 & 0.007 & 0.005 & 0.055 & 0.277 & 0.002 & -0.006 & -0.005 & 0.027 \\
\hline-8 & -0.007 & 0.001 & 0.001 & 0.007 & 0.045 & 0.322 & 0.000 & -0.006 & -0.002 & 0.024 \\
\hline-7 & -0.004 & -0.003 & 0.006 & 0.013 & 0.067 & 0.389 & 0.006 & 0.000 & 0.007 & 0.032 \\
\hline-6 & 0.000 & -0.004 & 0.006 & 0.019 & 0.030 & 0.419 & 0.001 & 0.001 & 0.006 & 0.037 \\
\hline-5 & 0.003 & -0.001 & -0.002 & 0.017 & 0.027 & 0.446 & -0.004 & -0.003 & 0.009 & 0.047 \\
\hline-4 & 0.002 & 0.001 & -0.005 & 0.012 & 0.038 & 0.484 & 0.007 & 0.004 & 0.002 & 0.048 \\
\hline-3 & 0.004 & 0.005 & -0.001 & 0.011 & 0.012 & 0.497 & 0.000 & 0.004 & 0.001 & 0.049 \\
\hline-2 & -0.007 & -0.002 & 0.004 & 0.014 & 0.028 & 0.524 & 0.002 & 0.006 & 0.000 & 0.049 \\
\hline-1 & -0.007 & -0.009 & 0.008 & 0.023 & 0.038 & 0.562 & -0.006 & 0.000 & -0.008 & 0.040 \\
\hline 0 & -0.008 & -0.016 & -0.002 & 0.021 & -0.018 & 0.544 & 0.002 & 0.002 & -0.016 & 0.024 \\
\hline 1 & 0.017 & 0.001 & -0.001 & 0.020 & 0.011 & 0.555 & 0.005 & 0.007 & 0.025 & 0.049 \\
\hline 2 & -0.024 & -0.023 & -0.002 & 0.018 & -0.002 & 0.553 & -0.005 & 0.002 & -0.007 & 0.043 \\
\hline 3 & -0.006 & -0.029 & -0.007 & 0.011 & 0.040 & 0.593 & 0.006 & 0.008 & 0.003 & 0.046 \\
\hline 4 & -0.007 & -0.036 & 0.004 & 0.015 & 0.056 & 0.648 & -0.001 & 0.006 & -0.001 & 0.045 \\
\hline 5 & 0.004 & -0.032 & -0.005 & 0.010 & 0.012 & 0.660 & -0.005 & 0.001 & -0.024 & 0.021 \\
\hline 6 & 0.000 & -0.032 & -0.009 & 0.001 & 0.053 & 0.713 & -0.003 & -0.002 & 0.010 & 0.031 \\
\hline 7 & 0.006 & -0.027 & 0.006 & 0.007 & 0.023 & 0.737 & -0.004 & -0.005 & 0.002 & 0.033 \\
\hline 8 & 0.002 & -0.025 & 0.004 & 0.011 & 0.055 & 0.791 & -0.001 & -0.006 & 0.003 & 0.036 \\
\hline 9 & -0.006 & -0.030 & 0.001 & 0.012 & 0.012 & 0.803 & -0.004 & -0.010 & -0.010 & 0.026 \\
\hline 10 & -0.004 & -0.034 & 0.001 & 0.013 & 0.012 & 0.815 & 0.008 & -0.002 & -0.007 & 0.019 \\
\hline 11 & -0.015 & -0.049 & -0.005 & 0.007 & 0.031 & 0.846 & 0.001 & -0.001 & 0.001 & 0.020 \\
\hline 12 & -0.008 & -0.057 & -0.007 & 0.000 & 0.040 & 0.886 & -0.009 & -0.010 & 0.018 & 0.038 \\
\hline 13 & -0.005 & -0.062 & -0.003 & -0.003 & 0.029 & 0.915 & 0.004 & -0.006 & -0.005 & 0.033 \\
\hline 14 & -0.005 & -0.067 & -0.005 & -0.008 & 0.065 & 0.980 & 0.005 & 0.000 & -0.025 & 0.008 \\
\hline 15 & 0.003 & -0.064 & -0.003 & -0.010 & 0.054 & 1.034 & -0.009 & -0.009 & 0.004 & 0.013 \\
\hline & & & & & & & & & & \\
\hline
\end{tabular}

Chart showing AAR of twenty companies for the period from 2001 to 2020.

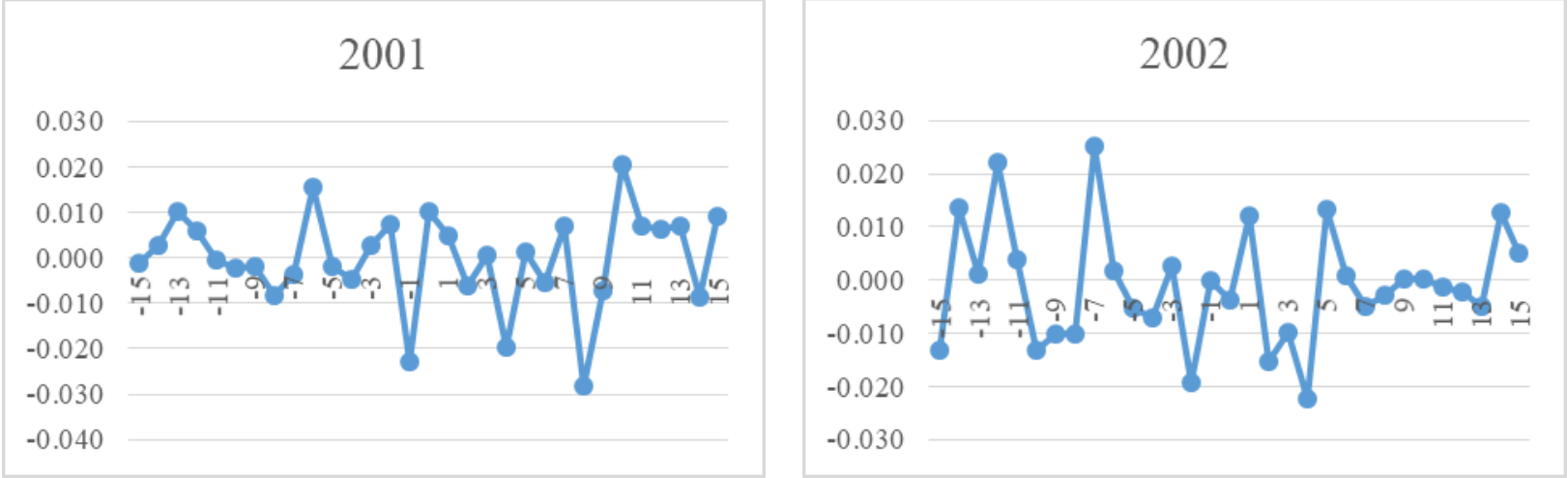

Chart $1 \& 2$ showing AARs Trends of 31- Day Event Window for the year $2001 \& 2002$. 

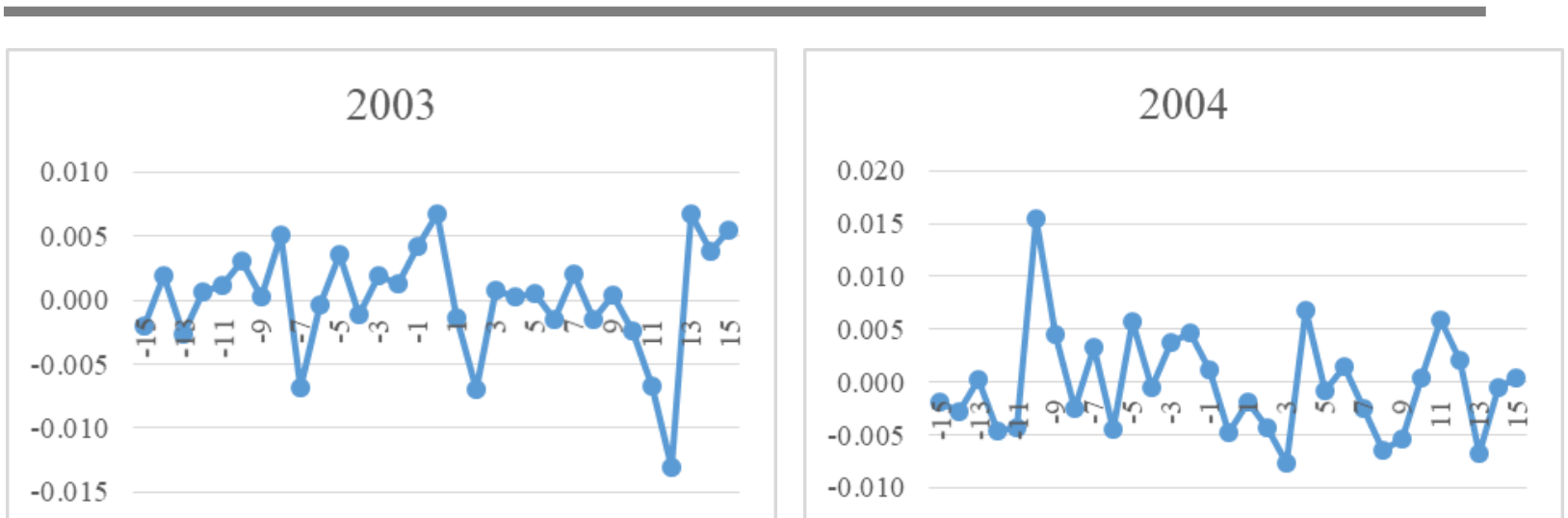

Chart 3 \& 4 showing AARs Trends of 31- Day Event Window for the year 2003 \& 2004.
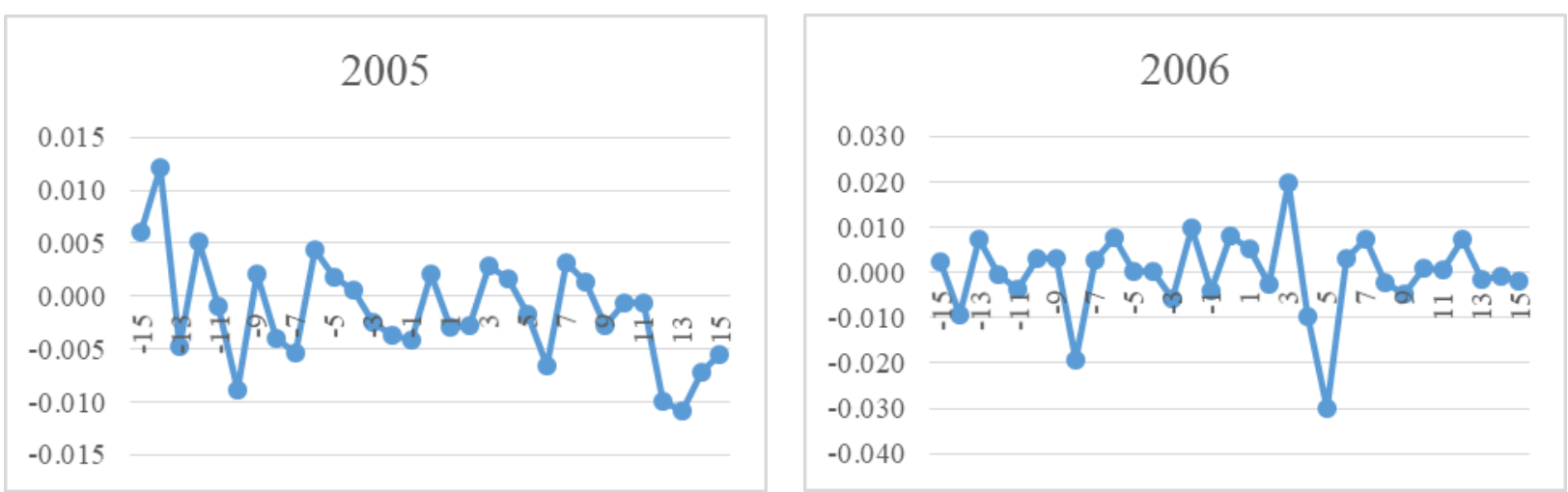

Chart 5 \& 6 showing AARs Trends of 31- Day Event Window for the year 2005 \& 2006.
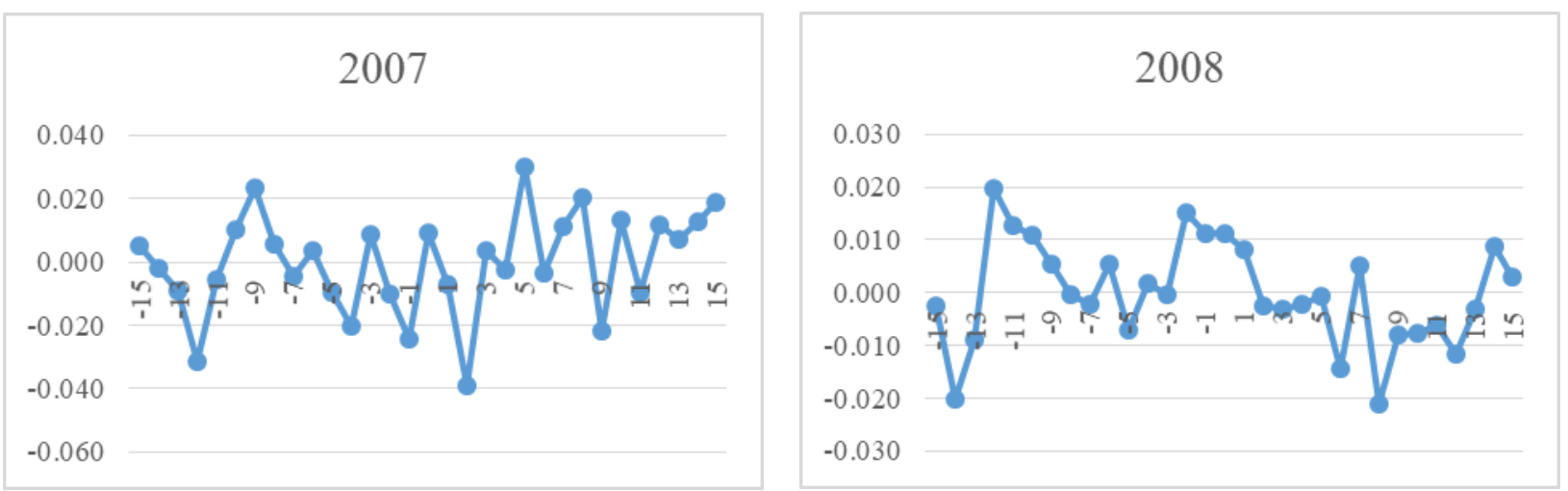

Chart $7 \& 8$ showing AARs Trends of 31- Day Event Window for the year $2007 \& 2008$. 

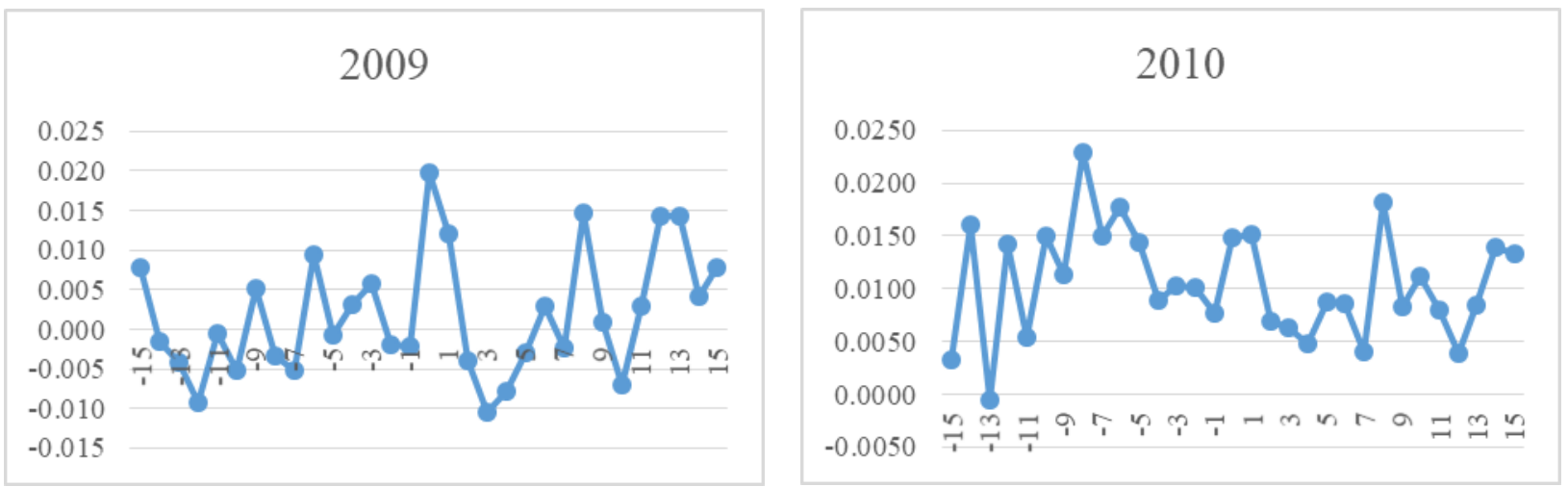

Chart 9 \& 10 showing AARs Trends of 31- Day Event Window for the year 2009 \& 2010.
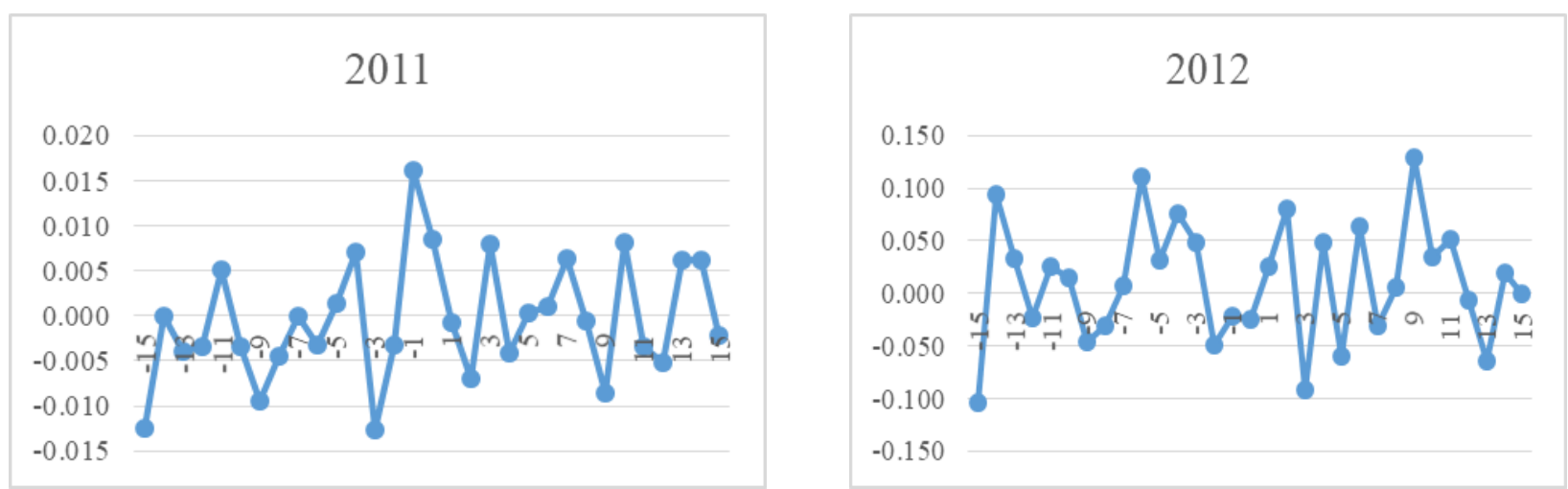

Chart $11 \& 12$ showing AARs Trends of 31- Day Event Window for the year 2011 \& 2012.
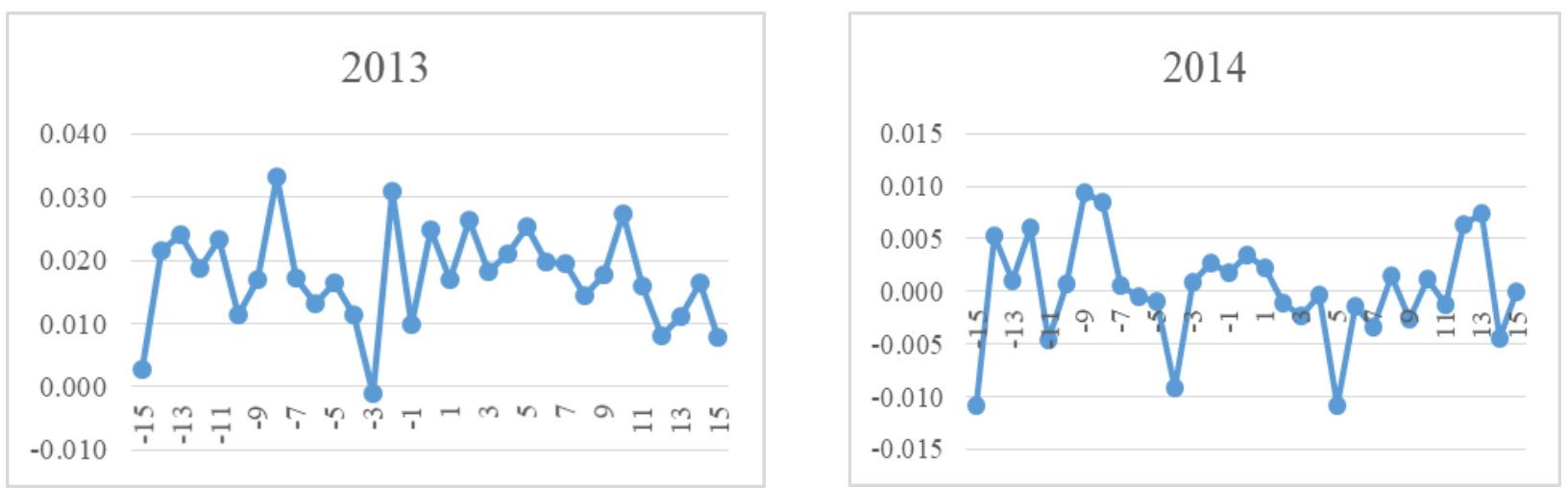

Chart 13 \& 14 showing AARs Trends of 31- Day Event Window for the year 2013 \& 2014. 

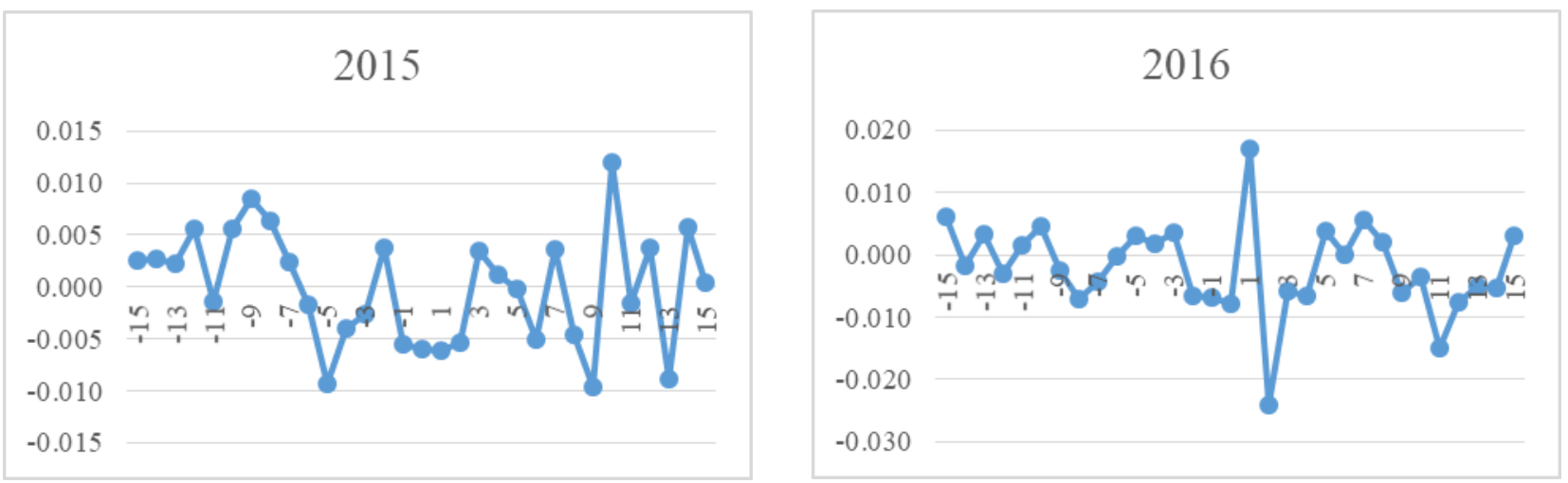

Chart 15 \& 16 showing AARs Trends of 31- Day Event Window for the year 2015 \& 2016.
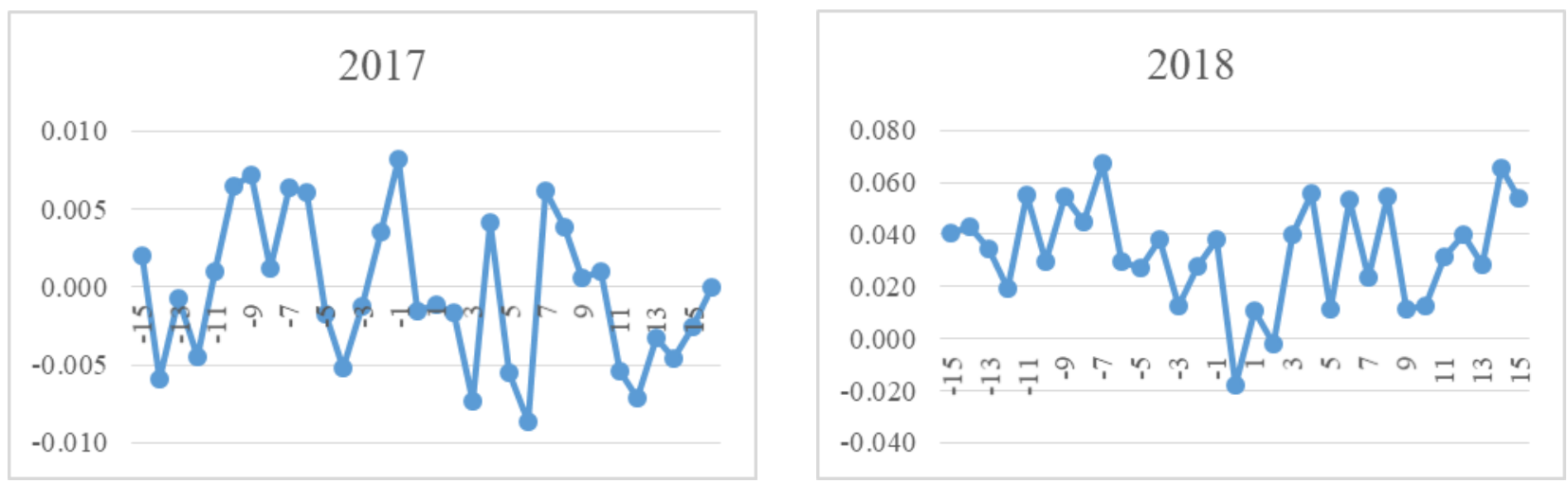

Chart $17 \& 18$ showing AARs Trends of 31- Day Event Window for the year 2017 \& 2018.
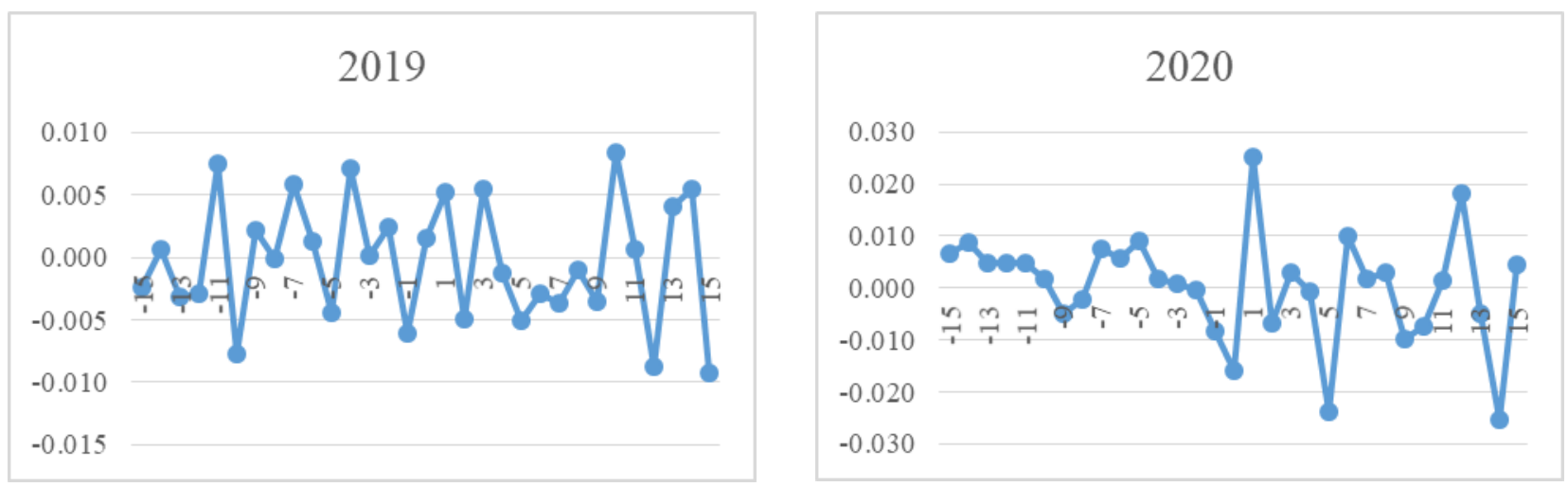

Chart 19 \& 20 showing AARs Trends of 31- Day Event Window for the year 2019 \& 2020. 